\title{
Husbandry Practice and Reproductive Performance of Indigenous Chicken Ecotype in Awi Zone, Amhara Regional State, Ethiopia
}

\author{
Andualem Yihun \\ Department of Animal Science, College of Agriculture, Injibara University, Injibara, Ethiopia \\ Email address: \\ andualemyihun95@gmail.com

\section{To cite this article:} \\ Andualem Yihun. Husbandry Practice and Reproductive Performance of Indigenous Chicken Ecotype in Awi Zone, Amhara Regional State, \\ Ethiopia. International Journal of Applied Agricultural Sciences. Vol. 6, No. 6, 2020, pp. 179-184. doi: 10.11648/j.ijaas.20200606.13
}

Received: October 2, 2020; Accepted: October 21, 2020; Published: December 4, 2020

\begin{abstract}
The study was conducted to generate comprehensive information on Husbandry practice and Reproductive performance of indigenous chicken ecotype in Awi zone in Adiss-kidame town in fagita district of Awi Zone, Amahara Regional State, Ethiopia. The study was performed based on household survey and observation. For household survey, three kebeles were selected and a total of 60 households (20 from each kebeles) were involved. Most of the household in the study area was practiced backyard chicken production systems (73.3\%). The major objective of raising chicken in the study area was egg production (46.7\%) and income generation (46.7\%). The majority of the households in the study area were practiced semiextensive management systems $(60 \%)$. The entire households in the study area were providing supplementary feed and water for their chicken. The age of cockerels at first mating and pullets at first egg laying were 5.21 months and 5.77 months, respectively. The entire households in the study area were hatching (brooding) the egg by using natural incubation hence broody hens used as a natural incubation method. Indigenous breeds of chickens are playing an important role in rural economies in most of the developing (underdeveloped) countries especially in Ethiopia. Since local chickens have good potential to adapt in different agro-ecology, Variations of disease and water shortage of the environments. They play a major role for the rural poor and marginalized section of the people with respect to their subsidiary income and provide them with nutritious of chicken egg and meat for their own consumption. This finding was baseline for understanding about Husbandry practice and Reproductive performance of indigenous chicken ecotype.
\end{abstract}

Keywords: Ecotype, Indigenous Chicken, Management, Performance

\section{Introduction}

Poultry production system in Ethiopia is indigenous and small flock, minimal input and unorganized marketing system [1]. Ethiopia is believed to have the largest livestock population. According to Central statistical agency [2], there are about 56.53 million chickens in Ethiopia, comprising of $94.31,3.21$ and $2.49 \%$ of indigenous, hybrid and exotic types, respectively.

In Ethiopia, most chicken populations are non-descriptive type. However, they showed a great variation in their production performance, which might be due to their wide spread distribution and adaptive response to different ecological conditions [3-6]. In Ethiopia a huge number $(95.86 \%)$ of Indigenous chicken is found in across different agro-ecological zones [7], under a traditional family-based scavenging management system. This indicates that they are highly important in farm animals kept as a good source of animal protein and income to most of the rural populations.

Therefore, the objective of this study was to designed with husbandry system and reproductive performance of indigenous chicken Ecotypes in Awi Zone Ethiopia.

\section{Material and Methodology}

\subsection{Description of the Study Are}

Fagita district is located in East-south to Awi Zone, Amahara Regional State, Ethiopia. Fagita district is bordered on the south by Banja Shekudad, on the west by Guangua, on the north by Dangila, and on the east by the Mirab Gojjam 
Zone. Towns in Faggeta Lekoma include Addis Kidame and Faggeta. The district is situated between $11^{\circ} 20^{\prime}$ North latitude and $36^{\circ} 45^{\prime}$ East longitude.

\subsection{Data Collection Methods}

\subsubsection{Questionnaire}

Both primary and secondary sources of data were used for the study. To collect the primary data, a semi-structured questionnaire was designed. The questionnaire was pre-tested before administration and some re-arrangement, reframing and correcting in accordance with respondent perception was done. The questionnaire was administered to the selected households or representatives by a team of researchers.

\subsubsection{Secondary Data Sources}

The secondary data was collected from the study district office of livestock and fishery resources to complement the production system and agro-ecology along with climate, vegetation cover, topography, human population and livestock population.

\subsection{Sampling Technique}

In order to conduct this study purposive and random sampling techniques was used. Purposive sampling method was used to select kebeles. Random sampling method was employed to select the study sample unit (Households) which was expected the representative at the whole population in the study area.

\subsection{Sampling Size}

From the total kebeles (22) found in the study area, three (3) kebeles were purposively selected. The selected Kebeles were more experienced in backyard chicken production and nearby to collect the data easily. Hence, by using random sampling technique 48 Households (16 Households from each kebeles) were selected for interview.

\subsection{Data Management and Statistical Data Analysis}

The data collected from each study site was checked for any error and corrected during the study period, coded and entered into computer for further analysis.

\subsection{Questionnaire Data}

Data collected through questionnaire was described by descriptive statistics using Statistical Package for Social Sciences (SPSS version 20.0. 2013). The results were presented in Table.

\section{Result and Discussion}

\subsection{Feed Resources and Feeding Management}

The major feeds and feeding practices of chickens in the study area as indicated by the respondents were reported in Table 1. The results showed that 85 of the Households feed their chicken with some kind of feed in addition to scavenging. The result was in agreement with the report of Halima [4], who reported that $99.3 \%$ of chicken owners in North West Amhara Region provided supplementary feeds to village birds. According to the results of this study, $15 \%$ were only scavenging around the backyard. In the current study farmers practiced supplementary feeding system use homegrown crops such as $41.18 \%, 15.68 \%, 11.76 \%, 13.72 \%$ and $17.66 \%$, like: wheat, maize, barely, sorghum and mixture with leftovers

The type of supplemental feeds varied based on the type of agricultural practice. The frequency of feeding showed that the majority of the respondents $(60.78 \%)$ was Feed chicken three times a day (morning, afternoon and evening), $21.57 \%$ and $17.65 \%$ were feed once and twice (morning and afternoon) respectively. The respondent farmers further reported that chicken were fed on ground $(54.90 \%)$, clay pot (21.57\%), wooden trough (17.65\%) and plastic (5.88\%) containers.

Table 1. Feed Resources and Feeding Practice.

\begin{tabular}{lll}
\hline Description & & \\
\hline Practice of Poultry Feeding & Frequency (N) & Percent (\%) \\
\hline Yes & 51 & 85 \\
No & 9 & 15 \\
Types of Feed Source with Leftover & & \\
Wheat & 21 & 41.18 \\
Maize & 8 & 15.68 \\
Barely & 6 & 11.76 \\
Sorghum & 7 & 13.72 \\
Mixture & 9 & 17.66 \\
Total & 51 & 100.0 \\
Frequency of Feeding & & \\
Twice / day & 9 & 17.65 \\
Once /day & 11 & 21.57 \\
Three or $>$ & 31 & 60.78 \\
Total & 51 & 100.0 \\
Types of Feeders Used & & \\
On ground & 28 & 54.90 \\
Plastic & 3 & 5.88 \\
Clay pot & 11 & 21.57 \\
Wooden through & 9 & 17.65 \\
Total & 51 & 100.0 \\
\hline
\end{tabular}

\subsection{Management of Watering Practice}

The results on provision of water to the chicken, based on respondent farmers responses, was presented in Table 2. The results showed that $93.33 \%$ of respondents provide water their chicken. This result was related with Bekele [8], who reported that $100 \%$ of chicken owners were provided water for their chicken.

The frequencies of watering showed that chicken were provided water ad-libitum (free aces), three times/day, Twice/day and once/day by $85.71 \%, 8.93 \%, 3.57 \%$ and $1.79 \%$ (overall figures) of respondent farmers in the study area. The major sources of household water were river, dam (pond), hand pump and spring water this are $(83.33 \%, 3.33 \%$ and $6.66 /$ $6.66 \%$, respectively). In contrast with Shishay [9], showed that well water $(31.7 \%)$, tap water $(29.1 \%)$, river $(27.3 \%)$, tap water and well water $(6.2 \%)$, river and tap water $(4.2 \%)$ as well as river and well water $(1.6 \%)$ sources of water in western 
Tigray.

In (Table 2) also showed that respondents use watering troughs clay pot $(35.18 \%)$, wooden $(31.48 \%)$, plastic $(16.67 \%)$, stone $(9.26 \%)$ and metallic $(7.40 \%)$ of farmers respectively. This was in line with the report of [10], in central Tigray; [11], in Southern Ethiopia and [5], in Bure district.

Table 2. Provision of Water, Watering Frequency, Sources of Water and Watering Trough.

\begin{tabular}{lll}
\hline Description & Frequency (N) & Percent (\%) \\
\hline Provision of Water & 56 & 93.33 \\
\hline Yes & 4 & 6.66 \\
No & & \\
Frequency of watering & 1 & 1.79 \\
Once /day & 2 & 3.57 \\
Twice / day & 5 & 8.93 \\
Three / day & 48 & 85.71 \\
ad-labium & 56 & 100.0 \\
Total & & \\
Source of water & 50 & 83.33 \\
River & 4 & 6.66 \\
Hand pump & 2 & 3.33 \\
Dam (pond) & 4 & 6.66 \\
Spring water & 56 & 100.0 \\
Total & & \\
Availability of watering through & 54 & 90 \\
Yes & 6 & 10 \\
No & 54 & 100.0 \\
Total & & \\
Types of watering through & 19 & 35.18 \\
Clay pot & 9 & 16.67 \\
Plastic & 17 & 31.48 \\
Wooden & 5.26 \\
Stone & 5 & 7.40 \\
Metallic & 4 & 100.0 \\
Total & 54 & \\
\hline
\end{tabular}

\subsection{Housing Management Systems in Fagita District}

As illustrated in Table 3, the majority $(60 \%)$ of the households in the study area were practiced semi-extensive management system. Based on the information collected from the respondents most of the households in the study area were have a separate chicken house $(86.7 \%)$. Similarly, Mammo [12], reported that, in south wollo, Ethiopia, about 41.3 percent of the households shared the same room followed by a separate quarter in the same roof ( 37.5 percent) and separately constructed houses 92.2 percent). According to the information obtained during the survey, the popular types of housing system in the study area were semiextensive or restricted range (63.3\%). (Table 3 ) In addition, majority of respondent households $(96.7 \%)$ were cleaned the poultry house daily.

Table 3. Poultry Housing System in Fagita district.

\begin{tabular}{lll}
\hline Description & & \\
\hline Availability of Poultry Housing & Frequency (N) & Percent (\%) \\
\hline Extensive & 22 & 36.7 \\
Semi-intensive & 36 & 60.0 \\
Intensive & 2 & 3.3 \\
Total & 60 & 100.0 \\
Do you have separate chicken house & & \\
\hline
\end{tabular}

\begin{tabular}{lll}
\hline Description & & \\
\hline Availability of Poultry Housing & Frequency (N) & Percent (\%) \\
\hline Yes & 52 & 86.7 \\
No & 8 & 13.3 \\
Types of housing systems & & \\
Extensive/free range & 20 & 33.3 \\
Semi -intensive/restricted range & 38 & 63.3 \\
system & 2 & 3.3 \\
Intensive/deep litter/cage & 60 & 100.0 \\
Total & 51 & \\
Do you practiced cleaning of chicken house & 96.7 \\
Yes & 9 & 3.3 \\
No & & \\
Frequency of Cleaning & 16 & 26.66 \\
Daily & 11 & 18.33 \\
In 2 Days & - & - \\
In 3 Days & 27 & 45 \\
Weekly & 6 & 10 \\
Monthly & 51 & 100.0 \\
Total & & \\
\hline
\end{tabular}

\subsection{Poultry Health Management}

The sources of diseases, Parasite and control measures, in the study areas was presented in Table 4. According to respondents in the study area, the incoming flock (either neighbor's flock or immigrants) was the major source of chicken infection $(53.33 \%)$ in the study area. Feleke [13], also reported that the major cause of death in local chicken was seasonal outbreak of NCD. And respondents from Quara discovered that the main sources of chicken disease were incoming and own flocks, respectively.

The majority of respondents $78.33 \%$ ) knew about parasitic infestation in fagita district. The indigenous practices, via: Smoking, Changing place, No intervention and spring medicine, were used to control parasitic infestation in the study areas. The overall results showed that $65.96 \%, 14.89 \%$, $6.38 \%$ and $12.76 \%$ of respondents practiced Smoking, Changing place, spring medicine and No intervention, respectively, for controlling parasitic infestation.

Table 4. Source of Disease, Parasite and Control Measures.

\begin{tabular}{lll}
\hline Description & & \\
\hline Source of disease & Frequency (N) & Percent (\%) \\
\hline Incoming flock & 32 & 53.33 \\
Own flock & 11 & 18.33 \\
Unknown & 17 & 28.33 \\
Farmer experience about Parasitic Infestation among Chicken & \\
Yes & 47 & 78.33 \\
No & 13 & 21.66 \\
Indigenous knowledge about prevention of external parasite & \\
Smoking & 31 & 65.96 \\
Changing place & 7 & 14.89 \\
No intervention & 3 & 6.38 \\
Spring medicine & 6 & 12.76 \\
Total & 47 & 100.0 \\
\hline
\end{tabular}

\subsection{Occurrence of Predator}

The occurrence of predators in the study areas was presented in Table 5; the majority proportion (98.33\%) of respondents reported that predators were occurring in the study areas. This result was in line with report of Halima [4], 
that predation was one of the major constraints in village chicken production in northwest Ethiopia. The most common predators mentioned by respondents were Vulture, wild Cat, Dog, Snake, Bee bitt and "sulsuly/fotte/" (locally available predators of wild animal in this area) in Table 5.

Local name sulsuly/fotte were wild animal predators common in all areas that attacks poultry in rainy seasons for the standing crops in the field were providing camouflage to these predators and poultry were becoming easy target due to this.

This result was in line with report of Halima [4], that predation is one of the major constraints in village chicken production in northwest Ethiopia. The average mean types of predators were $28.81 \%$ Vulture, $16.95 \%$ Cat and Dogs, $0 \%$ Snake, $15.26 \%$ and Bee bitt and 22.03\% Sulsuly/fotte/ of respondents were respond in the study areas respectively. This result was in agreement with Hunduma [14], reported that predators such as birds of prey (locally known as "Culullee") (34\%), cats and dogs (16.3\%) and wild animals $(15 \%)$ were identified as the major causes of village poultry in rift valley of Oromia, Ethiopia.

Table 5. Availability and Types of Predator in.

\begin{tabular}{lll}
\hline Description & & \\
\hline Occurrence of predator & Frequency $(\mathbf{N})$ & Percent $(\mathbf{\%})$ \\
\hline Yes & 59 & 98.33 \\
No & 1 & 1.66 \\
Types of predator & & \\
Vulture & 17 & 28.81 \\
Wild Cat & 10 & 16.95 \\
Dog & 10 & 16.95 \\
Snake & - & - \\
Bee bitt & 9 & 15.26 \\
Sulsuly/fote & 13 & 22.03 \\
Total & 59 & 100.0 \\
\hline
\end{tabular}

\subsection{Chicken Production System}

As illustrated in Table 6, the entire households in the study area were kept exotic chicken ecotype. The major sources of that chicken were Purchased from unknown sources $(60 \%)$ followed by Gift from governments (33.3\%). Based on the information obtained from the respondents, the major objective of raising chicken in the study area was egg production (46.7\%) and income generation (46.7\%). Similarly, Tadelle [3], reported that, village households in tropics like Ethiopia keep their chicken for purposes other than for reproduction, sale and consumptions, in particular for their socio-religious functions at home, gifts, for ceremonies and chicken are given as or received to show or to accept a good relationship or to say thanks for favor or help.

According to the information obtained during the survey, the main sources of local roosters in Fagita district was hatched at the house/flock $(63.3 \%)$ followed by purchased from unknown sources $(30 \%)$. According to the information obtained from the respondents, most of the household in the study area was practiced backyard chicken production systems (73.3\%). Similarly, Amsalu [15], reported that, the village chicken production system in Ethiopia followed the primitive type with 5-20 birds per households, simple rearing in backyard with inadequate housing, feeding and health care. Such production systems may result in slow growing, and poor layers of small sized eggs. Village chickens however are ideal mothers, good sitters, hatch their own eggs, excellent foragers and have immunities to resist common poultry diseases.

Table 6. Chicken Production systems in Fagita district.

\begin{tabular}{|c|c|c|}
\hline \multicolumn{3}{|l|}{ Description } \\
\hline Do you have exotic chicken & Frequency (N) & Percent (\%) \\
\hline Yes & 60 & 100.0 \\
\hline No & - & - \\
\hline \multicolumn{3}{|l|}{ Sources of exotic chicken } \\
\hline Gift from governments & 20 & 33.3 \\
\hline Gift from NGOs & 4 & 6.7 \\
\hline Purchased from unknown sources & 36 & 60 \\
\hline Total & 60 & 100.0 \\
\hline \multicolumn{3}{|l|}{ Purpose of keeping roosters } \\
\hline For meat production & 12 & 20.0 \\
\hline For sale & 2 & 3.3 \\
\hline For breeding purpose & 46 & 76.7 \\
\hline Total & 30 & 100.0 \\
\hline \multicolumn{3}{|l|}{ Sources of local roosters } \\
\hline Purchased from unknown sources & 18 & 30 \\
\hline Hatched at the flock/home & 38 & 63.3 \\
\hline Gift from NGOs & - & - \\
\hline Gift from governments & 4 & 6.7 \\
\hline Total & 60 & 100.0 \\
\hline \multicolumn{3}{|l|}{ Major objectives of raising chicken } \\
\hline Meat production & 4 & 6.7 \\
\hline Egg production & 28 & 46.7 \\
\hline Income generation & 28 & 46.7 \\
\hline Total & 60 & 100.0 \\
\hline \multicolumn{3}{|l|}{ Chicken production systems } \\
\hline Backyard chicken production & 44 & 73.3 \\
\hline Small scale chicken production & 16 & 26.7 \\
\hline Large scale chicken production & - & - \\
\hline Total & 60 & 100.0 \\
\hline
\end{tabular}

\subsection{Flock Structure and Ownership Pattern}

The proportion of different class of animals reflects the management decision of the producers, which in turn is determined by their production objective [16]. As illustrated in Table 7, the average number of chicken per household $(\mathrm{Mean} \pm \mathrm{SE}$ ) was $17.83 \pm 1.91$. Flock structure (Mean \pm SE) of chicken in the study area is presented in Table 7. In this study as compared to the other age groups layers made a major share $(6.93 \pm 1.22)$ in study district followed by pullets $(5.03 \pm 0.68)$.

Table 7. Flock structure of chicken in fagita district.

\begin{tabular}{ll}
\hline Flock composition of chicken & Mean \pm SE \\
\hline Number of chickens & $17.83 \pm 1.91$ \\
Number of chicks & $4.67 \pm 0.70$ \\
Number of pullets & $5.03 \pm 0.68$ \\
Number of layers & $6.93 \pm 1.22$ \\
Number of roosters & $1.63 \pm 0.17$ \\
\hline
\end{tabular}




\subsection{Reproductive Performance}

The least square mean of various production and reproduction traits (mean age at first service for cockerel in month, age at first egg laying of hen in month, number of clutch per year of local chicken, number of egg per clutch of local chicken, length of clutch in days for local chicken, total eggs per year of local chicken, interval between two consecutive broody periods, number of egg incubate for hatching per year and number of egg set to broody hen) of local chicken populations in the study area was presented in Table 8 .

The age at first service of cockerels was $5.22 \pm 0.03$ months in fagita district. Similarly the age at first laying of egg in hen were $5.74 \pm 0.05$ in the study area. This result was in line with the report of Mearg [17], overall mean age at first mating of male chickens and the age at first egg of female chickens were 5.29 and 5.96 months in central Tigray And smaller than with the report of Bogale [18], in which mean age of sexual maturity of indigenous chicken in Fogera district was $23.48 \pm 0.1$ and $23.6 \pm 0.11$ weeks for male and female respectively. The overall mean numbers of clutches per hen per year of local chicken ecotypes were $4.27 \pm 0.04$ in the study area. This result was in line with the findings of [19], who reported that the overall mean number of clutches per hen per year of local chicken ecotypes in western zone of Tigray was 4.42 . The overall mean number of egg per clutch of local chicken were $(14.38 \pm 0.25)$ the mean of the study area.

Table 8. Reproductive and Productive Performance of Local Hens Recalled by Respondents of the Study Areas (Mean \pm SE).

\begin{tabular}{ll}
\hline Variable & Frequency (N) \\
\hline Age at 1st service for cockerel (month) & $5.22 \pm 0.03$ \\
Age at 1st egg laying of hen (month) & $5.74 \pm 0.05$ \\
Number of clutch per year of local chicken & $4.27 \pm 0.04$ \\
Number of egg per clutch of local chicken & $14.38 \pm 0.25$ \\
Length of clutch in days for local chicken & $14.40 \pm 0.24$ \\
Total eggs per year of local chicken & $62.21 \pm 0.99$ \\
Interval B/NTwo consecutive broody period & $2.82 \pm 0.11$ \\
Times egg incubate for hatching per year & $2.80 \pm 0.10$ \\
Average egg set to broody hen & $12.50 \pm 0.3$ \\
\hline
\end{tabular}

The present result showed in Table 8, a number of egg per clutch was smaller as compared with findings of [17], who reported 15.20 eggs/clutch in central Tigray; [3], who reported 17.7 eggs/ clutch in five agro-ecology zones of Ethiopia; and [18], reported 16.6 eggs/clutch in Fogera district. However, present results were higher than those reported by Meseret [20], and Addisu [6], in which the mean egg number laid per clutch per hen of local chickens in Gomma wereda and North Wollo Zone were 12.92 and 12.64, respectively.

The overall mean length of clutch in days for cycle of local chicken were $14.40 \pm 0.24$ days, and The overall total number of eggs per year per hen $(62.21 \pm 0.99)$ in the study area. This result was similar with reports of Fisseha [5], and Mekonnen [11], who reported that the mean annual egg yield per hen of indigenous chickens in Bure district and Wonsho district were 60 eggs and 62.95 eggs. The number of eggs set to broody hen were $12.50 \pm 0.3$ of overall means. This result was higher than Mearg [17], who reported that the number of eggs incubated in midland and highland agro-ecologies were 11.4 and 11.4 , respectively in central Tigray.

\section{Conclusion and Recommendation}

The agricultural sector is a corner stone of the economic and social life of the people since they are used for generation of extra cash incomes, provision of animal protein and religious/cultural considerations of the people. Indigenous breeds of chickens are playing an important role in rural economies in most of the developing (underdeveloped) countries especially in Ethiopia. Since local chickens have good potential to adapt in different agroecology, Variations of disease and water shortage of the environments. They play a major role for the rural poor and marginalized section of the people with respect to their subsidiary income and provide them with nutritious of chicken egg and meat for their own consumption. Generally, chicken rearing system in the study area was mixed with crop- livestock production system using extensive management of indigenous chickens. The presences of various predators and diseases prevalence were two major economic important of chicken rearing constraints. According to the above discussion and conclusion the following recommendations are developed.

1. Farmers should be creating of awareness about chicken management system for the improvement of chicken products.

2. Research and developmental organizations should give attention to village poultry sector and its development.

3. The main problem for chicken production in the study area was reported to be disease. Therefore, efforts should be implemented to identify major chicken diseases, plan appropriate health control measures and introduce fast and efficient veterinary service.

\section{Acknowledgements}

We thank district's agriculture office experts and key informants of the community in the study area for understanding and passing the purpose of the assessment to the subordinates down to livestock farmers to the Kebele level. We are also grateful thanks to the interviewed farmers for their active participation in sharing their knowledge and time.

\section{References}

[1] Aberra, M. and Tegene, N. 2007. Study on the characterization of local chicken in Southern Ethiopia. Proceedings held in Awassa, March 16-17.

[2] (Central statistical agency).2016/17 [2009 E. C.] livestock and livestock characteristics (private peasant holdings); agricultural sample survey volume 2, federal democratic republic of Ethiopia, Addis Ababa, Ethiopia. 
[3] Tadelle, D., T. Million, and Alemu Yami \& K. J. Peters 2003. Village chicken production systems in Ethiopia: Use patterns \& performance evaluation and chicken products \&socioeconomic functions of chicken. Livestock Research for Rural Development 15 (1).

[4] Halima, H., Neser, F. W. C., van Marle-Koster, E. and De Kock, A., 2007. Phenotypic variation of native chicken populations in northwest Ethiopia. Tropical animal healthand production, 39 (7), pp. 507-513.

[5] Fisseha, M., 2010. Indigenous chicken production and marketing systems in Ethiopia: Characteristics and opportunities for market-oriented development (Vol. 24). ILRI (aka ILCA and ILRAD).

[6] Addisu, G. and Aschalew, T., 2014. A Phenotypic and Genetic Characterized Indigenous Chicken Ecotypes in Ethiopia. International Journal of Genetics, 4 (1), 04-10.

[7] CSA 2015. The federal democratic republic of Ethiopia central statistical agency, key findings of the 2014/2015 (2007 e.c.) agricultural sample survey Summary Report, September 2015, Addis Ababa, Ethiopia.

[8] Bekele, N., Urge, M., Ameha, N. and Fereja, G. B., 2014. Study of production practices, and productivity of village chicken in Chelliya District, Ethiopia. Science, Technology and Arts Research Journal, 4 (3), 117-122.

[9] Shishay Markos, Berhanu Belay and Tadelle Dessie. 2014. Incubation and Brooding Practices of Local Chicken Producers in Ethiopia: The Case of Western Zone of Tigray. Journal of Biology, Agriculture and Healthcare. Vol. 4, No. 25.

[10] Alem, A. T., Yayneshet, G. T. and Aklilu, A. H., 2014. Socioeconomic characteristics of poultry production in lowland and midland agro-ecological zones of central Tigray, Ethiopia. International Journal of Livestock Production, 5 (4); 71-80.

[11] Mekonnen, G., 2007. Characterization of the Small Holder Poultry Production and Marketing System of Dale, WonshoaNdola Abaya Woredaof SNNPRS, Ethiopia. MScThesis, Hawassa University, Hawassa, Ethiopia.

[12] Mammo, M. (2006). Survey on village chicken production under traditional management systems in Jamma woreda, south Wollo, Ethiopia. M. Sc. Thesis Presented to School of Graduate Studies of Alemaya University, Ethiopia.

[13] Feleke Assefa Argaw. 2015. Assessment of common practices of egg incubation and chick brooding of backyard poultry production system in Wolaita Zone, Southern Ethiopia: Vol. 3 (3), 162-168.

[14] Hunduma, D., Regassa, C., Fufa, D., Andale, B. and Samson, L., 2010. Major constraints and health management of village poultry production in rift valley of Oromia, Ethiopia. Global Veterinaria, 5 (1), pp. 6-10. Kenana cattle breed production systems in Sudan. Livestock Research for Rural Development. $18,56-61$.

[15] Amsalu, A. 2003. Practical poultry training manual. Amhara Region Agricultural Research Institute, Kombolcha Poultry Research and Multiplication Center.

[16] Solomon, G., Azage Tegegne, Berhanu Gebremedhin and Dirk Hoekstra, 2010. Sheep and goat production and marketing systems in Ethiopia: Characteristics and strategies for improvement. IPMS (Improving Productivity and Market Success) of Ethiopian Farmers Project Working Paper 23. ILRI (International Livestock Research Institute), Nairobi, Kenya. 58p.

[17] Mearg, F. E. A. R. G., 2016. Phenotypic characterization of local chicken ecotypes in the Central Zone of Tigray in northern Ethiopia (M. ScThesis, Jimma University).

[18] Bogale K., 2008. In Situ Characterization of Local Chicken Eco-Type for Functional Traits and Production System in Fogera District, Amhara Regional State. MSc Thesis Harmaya University, Haramaya, Ethiopia.

[19] Markos, S., Berhanu, B. and Tadelle, D., 2015. On Farm Performance Evaluation of Three Local Chicken Ecotypes in Western Zone of Tigray, Northern Ethiopia. Performance improvement, 5 (7).

[20] Meseret, M., 2010. Characterization of village chicken production and marketing system in Gomma Wereda, Jimma Zone, Ethiopia (Doctoral dissertation, Jimma University). 